\title{
CORRECTION
}

\section{Correction to: A Practical Guide to Delivering Nutritional Advice to People with Diabetes}

Pamela A. Dyson

(c) The Author(s) 2019

Published online: August 22, 2019

Correction to: Diabetes Ther (2019) 10:367-374

https://doi.org/10.1007/s13300-018-0556-4

In the original publication, part of acknowledgement text was missing and it should read as "For other work, not including this review paper, Pamela A. Dyson is part funded by the NIHR Oxford Biomedical Research Centre."
Open Access. This article is distributed under the terms of the Creative Commons Attribution-NonCommercial 4.0 International License (http://creativecommons.org/licenses/ by-nc/4.0/), which permits any noncommercial use, distribution, and reproduction in any medium, provided you give appropriate credit to the original author(s) and the source, provide a link to the Creative Commons license, and indicate if changes were made.

The original article can be found online at https://doi. org/10.1007/s13300-018-0556-4.

P. A. Dyson ( $\square)$

Oxford Centre for Diabetes, Endocrinology and Metabolism, University of Oxford, Oxford, UK e-mail: pamela.dyson_@ocdem.ox.ac.uk 